\title{
THE STUDY ON BRAND LOYALTY AND REPEAT PURCHASE INTENTION OF THE SHAMPOO MARKET IN COLOMBO
}

\author{
Jayasuriya. N.A*, Kodippili. N, Perera. K.M, \\ Priyadarshani. L \& Wijesekera. B.D \\ Business School, SLIIT \\ Malabe, Sri Lanka \\ E-mail-nisha.j@sliit.lk
}

\begin{abstract}
Brand Loyalty occurs when a customer is a lifelong fan of a particular brand. Loyal customers are always an asset to a company because they are their stable base of income. Customers who stay loyal towards one brand for a long period of time are those that even pass down their favorites to the next generations. On the other hand, repeat purchase intention is when a particular product has been purchased again-but due to the action of a previous purchases. When a customer purchases the same product again, this means that the product has a positive impact on the customer's behavior and that they really like it. When such situation applies to the purchase intention of several purchases afterwards- it can be clear that, that particular customer has started building brand loyalty towards that particular brand. This relationship is understood by many companies loyalty programs has been initiated The Sri Lankan shampoo market is cluttered with so many brands providing so many solutions, therefore it is a challenge for these companies to keep their customers to be loyal. The purpose of this research is to study whether brand loyalty has an impact on repeat purchase intention in the shampoo market in Sri Lanka while the objective is to identify the impact on brand loyalty and repeat purchase intention. For the purpose of this study, used non-probability convenience sampling technique has been used and selected a sample of 384 people residing in the Colombo district in Sri Lanka. One of the major findings of this research is that males use shampoo more than females in the Colombo district and one of the most favorite brands of the population is Dove. In conclusion, the study also proves that repeat purchase intention and brand loyalty has a positive relationship.
\end{abstract}

Keywords: Marketing; Brand Loyalty; Purchase Intention; Shampoo; Sri Lanka 


\section{Introduction}

In a world that is so dynamic and that has plenty of choice, staying loyal to brands is really hard. However, in spite of all the other options available, staying true to one particular brand is called brand loyalty. Having loyal customers is an asset to a company, because loyal customers will become advocated for that particular business. Brand fans or loyal customers are needed by companies to ensure that they have a stable base of business as well a firm foundation in which its marketing relies on. Loyal customers love to talk about their favorite brands, and word of mouth is the best way to convert potential new customers. Sri Lanka's shampoo market has a variety of products- providing many solutions to many hair related issues. This results in an ample supply of choices between brands in within brands itself. There is a tough competition that brands face when it comes to ensuring customers stay loyal-and how this becomes can be truly subjective. Customers stay loyal based on their experience they have had with the brand and the higher and favorable it ended, the higher likelihood for loyalty.

Repeat purchase intention on the other hand is when one particular customer purchases a product again based on their previous purchases. This group of repurchasing customers are a vital group for businesses because they are those that keep the business running. This group of customers are the most profitable for a company therefore it is crucial that companies need to hold on to these customers. In the shampoo market in Sri Lanka, there are so many different types of products providing so many different types of hair care solutions. In such a case, it is always a challenge for companies to keep customers attached with a brand so that they will keep repurchasing them. In addition to this, the shampoo market is so competitive that is easy for a customer to tend to switch between products.

Research conducted in the area of brand loyalty and purchase intention on Fast Moving Consumer Goods (FMCG) products in shampoo market. Because lack of researches conducted on Sri Lankan context regarding shampoo market. Hence, this research aims to study if there is a relationship between brand loyalty and repeat purchase intention. 


\section{Theoretical Underpinning}

\subsection{Brand loyalty}

As defined by the American Marketing Association (AMA), brand loyalty is the situation when a consumer generally buys the same service/ product from the same supplier repeatedly over a period of time rather than purchasing from multiple sellers who sell within the same category.

If loyal customer has deep loyalty towards any product or service, he/she willing to repurchase that product or service in the future. Because it could satisfy the reason behind purchase that product or service. Habib and Aslam (2014)(as cited inOliver, 1997).Factors like price and convenience are not even considered in a situation like this, since the customer knows exactly what they want, and they need exactly that. In a general typical scenario, a consumer's purchase is based on 3 scenarios- one, a consumer buys a product which is more familiar to them or two, the customer already has used/ tried the product or even three, is recommended by another friend who is an advocate for the brand. Furthermore, according to Tharmi and Senthilnathan (2011)a powerful brand influences attitudes of customers and makes a strong product association through the brand. Business industrialists uses different creative marketing strategies like loyalty programs, social media and brand ambassadors to create brand loyalty.

\subsection{Repeat purchase intention}

According to Habib and Aslam (2014)as cited from Morgan and Rego (2006), repurchase intentions are the most widely used indicator of customer loyalty in the customer feedback systems used in companies. Suryadi (2015)as cited from Chang (1998), that the prospect of buying must support the desired product approach, otherwise kindness or purchase Intentions will be in vain. Based on a customers' purchase history, they will continue to purchase products repeatedly since the purchase intension is the likelihood of a customer. For a consumer to purchase a product there should arise a purchase intention for them to buy that certain product or else there should arise a need for a product for a customer to buy that product. When such a situation happens- this is one of the most complex scenarios faced by companies. Figuring out what is running inside their target customers' head is challenging and due to its complexity makes it hard to understand. This is because of the choice available in the market and this enabling ample choice for customers to shift 
immediately to other brands. Due to this reason, purchase intentions are the most widely used indicator of customer loyalty in firms' customer feedback systems (Habib \& Aslam, 2014). Purchase intention is the hidden promise to someone's self to purchase the product continuously whenever re-visit to the market.This is because a customer will continue to purchase products repeatedly based on their purchase history. For a consumer to purchase a product there should be a situation when they remember their previous purchase and enable them to only buy that certain product or else there should arise a need for a product for a customer to buy that particular product. The objective of purchasing customers can be changed by various factors such as price and quality of a product or service. Moreover, when a product has a basic importance or when a product has a value for the customers, they tend to elaborate the product. Dodds, Monrore, and Grewal (1991) proposed, purchase intention means the actions for customers to purchase to products. Lin and $\mathrm{Lu}$ (2010, p. 20)as cited from Blackwell, Miniard, and Engel (2001)suggested this purchase intention includes 'subjective judgement for future behavior.' That mean purchase intention means for what consumer would like to purchase in the future $\mathrm{Lin}$ and $\mathrm{Lu}(2010)$ as cited from Shao, Baker, and Wagner (2004), recommend purchase intention point out to the attempt to make purchase a product or to go a market offering services. If customers have a positive purchase intention towards a particular shampoo brand, then they will re purchase it again when the same need arises again. The consumers will then be willing enough to purchase that particular brand continuously and eventually settle to retain with that particular brand in the long term.

According toTharmi and Senthilnathan (2011)as cited from Vranesevic and Stancec (2003)the importance of a brand basically highlighted through measuring the brand impacts on choice and loyalty of consumers with the identification and differentiation of a product's quality, according to(Habib \& Aslam, 2014)as cited from Schultz (2005)loyal customer's likes to speak about their brand and they often recommend those brands to their closer ones. Loyalty can be in two dimensions either the purchase or attitudinal. And according to (Hameed \& Kanwal, 2018)as cited fromYoon and Kim (2000), a loyal customer will pay higher prices for the product that satisfy its needs and wants even prices of the products increases. According to(Habib \& Aslam, 2014)as cited from Anderson, Fornell, and MAzvancheryl (2004), a loyal consumer can help an organization to increase its bargaining power regarding its partner and suppliers Habib and Aslam (2014)based from the works from(Dick \& Basu, 1994)argued that a loyal customer of firm will creates positive Word of Mouth 
regarding company and product and competitive strategies of organization competitor will not impact loyal customer. Therefore, purchase intention is directly linked with brand loyalty.

\section{Design/Methodology/Approach}

\subsection{Design}

This research was conducted according to the descriptive research design method which is used to describe the characteristics of a population or phenomenon being studied and this will help to examine the impact of brand loyalty y on purchase intention of shampoo products in Sri Lanka.

\subsubsection{Research method and sample design}

This study adopted both quantitative and qualitative methods and was focused on collecting numerical data for statistical analysis. The reason to use both quantitative and qualitative methods was to generate numeric data or data that can be transformed into usable to understand the underlying reasons and opinions respectively. In addition to this, the reasons for a consumer to reach out for a particular brand is purely subjective, hence the need to use both of these methods.

The target market selected for this research is based on Sri Lanka's commercial city district- Colombo which has a population of 752,993 people. This was selected due to the proximity of the target audience.

\subsubsection{Sampling technique and sample size}

The non-probability convenience sampling technique was used to conduct this research. This technique was utilized since the easiest sampling technique under nonprobability sampling also given the time and budgetary restrictions that had to be faced when conducting the research. In convenience sampling the participants are selected based on availability and willingness to take part.

The sample size selected for this research is 384 and this number was derived from the Persian Morgan Table. 


\subsubsection{Method of data collection}

Data for this research was conducted using primary data since this research was conducted in the Sri Lankan context.

\subsection{Methodology}

\subsubsection{Reliability}

Table 1: Factor Analysis of Brand Loyalty

\begin{tabular}{|c|c|c|c|}
\hline Variable & $\begin{array}{c}\text { Initial No. of } \\
\text { Items }\end{array}$ & Final Items & Cronbach's Alpha \\
\hline Brand Loyalty & 5 & 3 & .711 \\
\hline
\end{tabular}

The Reliability of the questionnaire used for this research was measured by Cronbach's alpha. In the Table 1, the Cronbach's alpha has reduced to 0.711 and it can be considered as acceptable since the alpha value is greater than 0.7 and is closer to an alpha value of 1 .

\subsubsection{Demographic characteristics}

\section{Table 2: Demographic}

\begin{tabular}{|l|l|l|l|}
\hline \multirow{3}{*}{ Gender } & & Frequency & Percentage \\
\cline { 2 - 4 } & Male & 193 & $50.3 \%$ \\
\cline { 2 - 4 } & Female & 191 & $49.7 \%$ \\
\hline
\end{tabular}

Analyzing the data collected from the final survey Table 2, it was found that $50.3 \%$ of the majority were males who use shampoo while the rest $49.7 \%$ are the females who use shampoo.

Table 3: Age Groups

\begin{tabular}{|l|l|l|l|}
\hline \multirow{4}{*}{ Age } & $18-25$ & 122 & $31.8 \%$ \\
\cline { 2 - 4 } & $26-33$ & 137 & $35.7 \%$ \\
\cline { 2 - 4 } & $34-41$ & 111 & $28.9 \%$ \\
\cline { 2 - 4 } & $42-49$ & 10 & $2.6 \%$ \\
\cline { 2 - 4 } & Above 50 & 4 & $1.0 \%$ \\
\hline
\end{tabular}


When considering the second demographic factor which is age Table 3 ,. It is categorized as 18-25, 26-33, 34-41, 42-49 and above 50. From the data collected through the final survey, there were only 122 people who are under the age category of $18-25$. Majority, which is $35.7 \%$ of the people who use shampoo are the young people who are at the age category of 26-33. Under the age category of 26-33, there are only $35.7 \%$ of both males and females who use shampoo. The shampoo usage of adults is lower than the shampoo usage of the youth. Furthermore, when considering the age categories of $34-41$ and above 50 there is only $28.9 \%$ and $1 \%$ shampoo users respectively. It can be seen that the age limit of above 50 has the least amount of shampoo users which is only $1 \%$. From this data set collected it can be concluded that majority of the shampoo users are the youth.

\section{Table 4: Occupation of Population}

\begin{tabular}{|l|l|l|l|}
\hline \multirow{5}{*}{ Occupation } & Student & 81 & $21.1 \%$ \\
\cline { 2 - 4 } & Housewife & 61 & $15.9 \%$ \\
\cline { 2 - 4 } & Public sector & 58 & $15.1 \%$ \\
\cline { 2 - 4 } & Private sector & 76 & $19.8 \%$ \\
\cline { 2 - 4 } & Entrepreneur & 85 & $22.1 \%$ \\
\cline { 2 - 4 } & Unemployed & 23 & $6.0 \%$ \\
\hline
\end{tabular}

When considering occupation Table 4 majority which is $22.1 \%$ of the people are entrepreneurs. Out of the 384 responses, 81 are students who use shampoo in their day to day life to wash their hair. Least number of shampoo users are in the category of unemployed which is only $6 \%$.

\subsubsection{Popular choice}

The below word cloud Figure 1 shows that the most popular and used shampoo brands in Sri Lanka. Based on the word cloud the majority of the sample use the brand Dove to wash their hair. Clear shampoo has the second highest usage while L'Oreal has the third highest usage. Since Dove shampoo is being used by majority of the respondents it can be concluded that the Dove shampoo possess all the qualities which a consumer is seeking. Lux, Head \& Shoulders Oribe, Body Shop and many other shampoos are being used at a minimum quantity. It might be because the consumers do not get the needed output from those shampoo brands. Furthermore, based on the survey, $80 \%$ of the respondents use bottled shampoo and only $11 \%$ of the respondents use shampoo (packets).

Journal of Business Studies, 7(1)

$-155-$

2020 


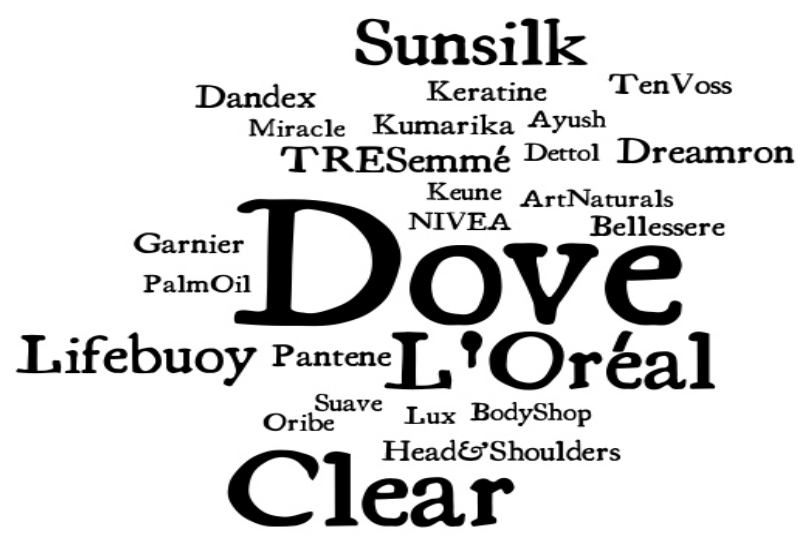

Figure 1: Shampoo Brands Usage

Table .5: Reliability Analysis of Brand Loyalty

\begin{tabular}{|lccccc|}
\hline Item & \multicolumn{2}{c}{ Descriptive Statistics } & \multicolumn{3}{c|}{ Inter Item Correlation } \\
\hline & Mean & SD & BL20 & BL21 & BL22 \\
\hline BL20 & 2.80 & 1.255 & 1.000 & .421 & .410 \\
\hline BL21 & 2.75 & 1.200 & .421 & 1.000 & .536 \\
\hline BL22 & 2.98 & 1.218 & .410 & .536 & 1.000 \\
\hline
\end{tabular}

Table 5.1: Questions of Brand Loyalty

\begin{tabular}{|l|l|}
\hline Question No. & \multicolumn{1}{c|}{ Question } \\
\hline BL20 & I use this shampoo because it is popular \\
\hline BL21 & When I need to buy shampoo, I think of any shampoo brand \\
\hline BL22 & I keep changing shampoo brands constantly \\
\hline
\end{tabular}

Based on Table 5, the level of agreement in all 3 items is in the agreeable level. The highest correlation for each item with at least one other item in the construct is between 0.3 and 0.9. In factor analysis the $\mathrm{KMO}$ value was 0.657 which is closer to 0.7. A single factor was extracted that explains $63 \%$ of the total variation in the 3 items. The mean for the 3 items was computed and saved as Brand Loyalty to be used in further analysis.

Furthermore, when considering the KMO measure of sampling adequacy, there is a value of 0.657 which is in between 0.60 and 0.69 . Since it is in between 0.60 and 0.69 , it can be considered as mediocre which is also acceptable. From this it can be said that, there is common variance in the correlation matrix and certainly it is appropriate to 
analyze in factor analysis. According to the findings done in this research, the cumulative percentage in the extraction sums of squared loading was $63.340 \%$. From the Brand Loyalty factor, which is being extracted it explains $63 \%$ of the variation in the 3 items. It is recommended that the cumulative percentage should be above $60 \%$ and in the brand loyalty factor, the cumulative percentage if above $60 \%$.

\subsubsection{Correlation}

Table 6: Correlation Analysis of Brand Loyalty

\begin{tabular}{lll}
\hline \multirow{2}{*}{ Brand Loyalty } & \multicolumn{1}{c}{ Correlation } \\
\cline { 2 - 3 } & Brand Loyalty & Purchase Intention \\
\cline { 2 - 3 } & Pearson Correlation & $.481^{* *}$ \\
\cline { 2 - 3 } Sig (2-tailed) & .000 \\
& 384 \\
\hline
\end{tabular}

Based on the above table, when Brand Loyalty and Purchase Intention is taken into consideration, it can be seen that there is an $r$ value of 0.481 which indicates a positive moderate correlation. In addition, there is a significance value of 0.000 which can be considered as highly significant. it can be concluded that there is a statistically significant correlation between the two variables which are Brand Loyalty and Purchase Intension. This means, an increase or decrease in one variable is significantly related to increase or decrease in the other variable.

\subsubsection{Regression}

Table 7: Regression Analysis of Brand Loyalty

\begin{tabular}{|c|c|c|c|c|c|c|}
\hline \multicolumn{7}{|c|}{ Coefficients } \\
\hline \multicolumn{2}{|c|}{ Model } & Understandadized & Coefficients & Standardized & $\mathrm{t}$ & Sig. \\
\hline \multirow[b]{2}{*}{1} & (Constant) & 1.175 & .156 & & 7.555 & .000 \\
\hline & Brand Loyalty & .320 & .033 & .420 & 9.557 & .000 \\
\hline
\end{tabular}


In the above table, the p-value for brand loyalty is less than 0.05 . Hence, repeat purchase intention depends on brand loyalty. When considering the $\mathrm{R}^{2}$ value, it explains how much the total variation in the dependent variable (purchase intention) can be explained by the independent variable (brand loyalty).

H1-Repeat purchase intention has a significant impact on Brand Loyalty.

\subsubsection{Summary of Regression Analysis}

Table No.8: Summery of Regression Analysis

\begin{tabular}{llll}
\hline No. & Hypothesis & P-Value & Conclusion \\
\hline H1 & There is a relationship between brand & $<0.05$ & Supported \\
& loyalty and purchase intention. & &
\end{tabular}

\section{Objective 1:To identify the impact of brand loyalty on purchase intention of shampoo products in Sri Lanka.}

As per the regression analysis, brand loyalty and purchase intention have a positive relationship where the significant value is 0.000 which indicates that the test results statistically significantly predicts the outcome variable. Moreover, since the significance value was below 0.05 it is being supported by data. Through the results generated in this study, it can be indicated that the test results showed brand loyalty has an impact on purchase intention.

\section{Findings}

H1: There is an impact of brand loyalty on purchase intention.

As per the regression analysis there is a positive relationship with a significance value of 0.000 which supports the hypothesis. Brand loyalty also plays a major role in the purchase intention of consumer products. A research done by on the effect of brand loyalty on purchase intention in cosmetic industry, evaluates that how much buying behavior of consumer are influenced by brand loyalty. The results of this research had shown a positive significant impact on brand loyalty on purchase intention.

The results obtained from the study is in line with the researches done in the past. According to there are six variables which influence the brand loyalty which are product quality, design, brand name, price, promotion and store environment. The 
loyal customers will buy a product repeatedly and will be ready to pay extra price for their desired product which in turn enhance the profits and sales of the firm. Therefore, prices cannot affect the purchase intention of these customers. When considering promotion, it can be identified as a source of providing information about their brand to the consumers. Therefore, advertising makes it easy to create a good image in the minds of the consumers about the product. Young people like to use brands which are being communicated by celebrities to promote the brand and also promotions help to compel brand switchers towards a brand and build up brand loyalty. When design of the product is taken into consideration, the fashion-conscious customers are being attracted towards a brand which supply stylish packages. The fashion lovers and the leaders of fashion will tend to purchase the products continuously because of its design and high fashion. Product quality on the other hand is very much related to perception and it is an essential quality of brand loyalty. Nowadays customers are more aware of the products in the markets and consider quality as an important aspect and are unwilling to compromise on quality. When considering store environment, the attributes like store place, interior, layout of the store effect brand loyalty. The location of the store is very important because if the store location is out of reach it will indirectly impact on the purchasing pattern and consumers will switch to other brands rather than going in search of the brand to another shop. The final variable, which is brand name, is anything which is used to differentiate the product from other competitors' products. These can be in terms of design, sign or any other factor. A study examined that hard-core loyal customers and brand switchers are distinguished with the help of brand name. In conclusion, purchase intention depends on the consumers' ability to pay. When there is enough money for a consumer they do not consider about the price of the product. Moreover, when consumers have more purchase intention, then consumers will be more loyal towards a brand. When considering brand name, it is very important to purchase intention and brand loyalty since brand name shows the image or reliability of the product.

Brand loyalty is hard to establish, and in the last few decades it has become a big challenge for the marketers due to the increasing competition. The loyal customers can be passive repeaters and also, they spread positive word of mouth while defending the brand against competing brands. In other words, these customers will purchase products continuously since they are loyal to the brand and once they are satisfied with the brand, they will be spreading a good word of mouth which will eventually increase sales and profits to the business. 


\section{Research Limitations}

One of the main limitations faced in this research is the time and budget to ensure that the sample was conducted beyond the Colombo district. The questionnaire also was limited with only 32 questions and this restricted from including more detailed questions for better evaluation. In addition to this, Fast Moving Consumer Goods (FMCG) companies do not release the market research and their solutions to how they overcome such problems since they are confidential company data. If these findings were available, it would have been much easier to understand any trend/ variations between these variables and deepen the findings of this research.

\section{Originality}

This originality of this research lies in the aspect that limited research on this area has been done based in Sri Lanka. Even though there is seen to be a handful of research done regards FMCG brands abroad as discussed in the theoretical underpinning and findings sections, specific research on the shampoo market in Sri Lanka is limited. In addition, this research was able to identify that more male consumers use shampoo as opposed to the generally perceived female consumers and the most favored brand is Dove. The most common age range is $26-33$ which is the youth of Sri Lanka. Looking at the occupations, most of those who do use shampoo are entrepreneurs. Dove is a pricy shampoo and the affordability of this (price) could be a reason this sample prefers Dove as product for prestige. Since there is a lack of published articles under this area of study, it will be very useful for the academia to further research on this while also enabling marketers and senior management teams to make use of this data as a guide to prepare sound and strategic marketing plans for their beloved companies.

Journal of Business Studies, 7(1)

$-160-$

2020 


\section{References:}

Anderson, E., W, Fornell, C., \& MAzvancheryl, S., K. (2004). Customer satisfaction and shareholder value. The journal of marketing, 68(4), 172-185.

Blackwell, R., D, Miniard, P., W, \& Engel, J., F. (2001). Consumer Behavior (Vol. 4). London: Harcourt College Publishers.

Chang, M., K. (1998). Predicting unethical behavior: a comparison of the theory of reasoned action and the theory of planned behavior. Business Ethics, 17, 18251834.

Dick, A., S, \& Basu, K. (1994). Customer loyalty towards an integrated framework. Journal of the Academy of Marketing Science, 22(2), 99-113.

Dodds, W., B, Monrore, K., B, \& Grewal, D. (1991). Effects of Price, Brand and Store Information on Buyers' Product Evaluations. Journal of Marketing Research, 28, 307-319.

Habib, S., \& Aslam, S. (2014). Influence of brand loyalty on consumer repurchase intentions of coca-cola. Business and Management, 6(14), 168-175.

Hameed, S., \& Kanwal, M. (2018). Effect of brand loyalty on purchase intention in cosmetics industry. Research in Business and Management, 5(1), 25-35. doi:10.5296/rbm.v5i1.12704

Lin, L., Y, \& Lu, C., Y. (2010). The influence of corporate image, relationship marketing, and trust on purchase intention: the moderating effects of word-ofmouth. Tourism Review, 66(3), 16-34.

Morgan, N., A, \& Rego, L., L. (2006). The value of different customer satisfaction and loyalty metrics in predicting business performance. Marketing Science, 25(5), 426-439. doi:10.1287/mksc. 1050.0180

Oliver, R., L. (1997). Satisfaction: A behavioral perspective on the consumer: McGraw Hill.

Schultz, D., E. (2005). The loyalty paradox. Marketing Management, 14(5), 10-11.

Shao, C., Y, Baker, J., A, \& Wagner, J. (2004). The Effect of Appropriateness off Service Contact Personnel Dress on Customer Expectations of Service Quality and Purchase Intention: The Moderating Influences of Involvment and Gender. Journal of Business Research, 57(10), 1164-1176. 
Suryadi, D. (2015). The impact of brand equity towards purchase intention on PT. X's candy. iBuss Management, 3(2), 1-8.

Tharmi, U., \& Senthilnathan, S. (2011). The Relationship of Brand Equity to Purchase Intention. SSRN Electronic Journal. doi:10.2139/ssrn.1935740

Vranesevic, T., \& Stancec, R. (2003). The effect of the brand on percieved quality of food products. British food journal, 105(11), 811-825.

Yoon, S., J, \& Kim, J., H. (2000). An empirical validation of a loyalty model based on expectation and disconfirmation. Journal of Consumer Marketing, 17(2), 120136. 